\title{
Bare Sticks and Naked Pity : Rhetoric and Representation in Qing Dynasty (1644-1911). Capital Case Records
}

Thomas Buoye

\section{(2) OpenEdition \\ Journals}

Electronic version

URL: http://journals.openedition.org/chs/1485

DOI: $10.4000 /$ chs. 1485

ISSN: 1663-4837

Publisher

Librairie Droz

\section{Printed version}

Date of publication: 1 October 2014

Number of pages: $27-47$

ISBN: 978-2-600-01854-8

ISSN: 1422-0857

Electronic reference

Thomas Buoye, «Bare Sticks and Naked Pity: Rhetoric and Representation in Qing Dynasty

(1644-1911). Capital Case Records », Crime, Histoire \& Sociétés / Crime, History \& Societies [Online], Vol.

$18, n^{\circ} 2$ | 2014, Online since 01 October 2017, connection on 19 April 2019. URL : http://

journals.openedition.org/chs/1485; DOI : 10.4000/chs.1485 


\title{
Bare Sticks and Naked Pity: Rhetoric and Representation in Qing Dynasty (1644-1911) Capital Case Records
}

\author{
Thomas Buoye
}

Cet article examine la rhétorique et les représentations inhérentes aux dossiers des procès capitaux chinois du XVIII siècle, période où la peine de mort fut étendue aux «bâtons nus», terme argotique désignant les hommes marginaux portés à la délinquance. Les empereurs Qing, en adoptant une politique pénale combinant le «profilage criminel» et le caractère supposément dissuasif de la peine capitale présentaient un sérieux défi à la bureaucratie judiciaire. Au plan idéologique, l'imposition de sentences cruelles et le ciblage des «bâtons nus» suscitaient un dilemme pour les magistrats locaux qui opéraient dans les limites d'une procédure de jugement et d'un système judiciaire étroitement bureaucratisés. Cet article argumente que ces magistrats utilisaient les dossiers judiciaires pour présenter sous un jour sympathique la pauvreté et le désespoir ruraux, en allant à l'encontre des dénonciations impériales de la criminalité violente. Selon un ethos judiciaire traditionnellement porté à l'indulgence et à la sauvegarde de la vie leitmotivs de la justice pénale chinoise depuis des siècles - ces représentations jouaient sur les émotions pour clairement faire savoir au pouvoir central que plutôt que les déficiences morales des "bâtons nus », c'étaient les conditions économiques qui jouaient un rôle important dans la fragilisation de la famille et de l'ordre social.

This article examines the rhetoric and representation of Chinese capital case records from the eighteenth century, when, as part of a far-reaching crackdown on violent crime, the use of capital punishment was extended to crimes committed by 'bare sticks', a common term for the underclass of crime-prone males. Adopting a strategy to suppress crime that combined 'criminal profiling' with the presumed deterrent power of capital punishment, Qing emperors presented serious challenges to the judicial bureaucracy.

Thomas Buoye is Associate Professor of History and Department Chair at the University of Tulsa and Research Associate at the Center for Chinese Studies at the University of Michigan. He earned his $\mathrm{PhD}$ from the University of Michigan, in 1991. He is currently working on two projects: Capital Crime and Criminal Justice in Eighteenth-century China and Ruler, State and Economy in Eighteenth-Century China: The Economic Role of the Qing Imperial Household Department. His main publications include: Manslaughter, Markets, and Moral Economy: Violent Disputes over Property Rights in Eighteenth-Century China, Cambridge, CUP, 2000; Criminal Justice in China: The Place of Incarceration', China Review International, 2012, 18, 1, pp. 14-18. Sanctimony and Self-deception: The Eighteenth-Century Origins of Western Misperceptions of Chinese Capital Punishment, Studies in Chinese History, 2013, 23, pp. 1-26; Evenhandedness and Excess: The Diverse Fates of Ethnic Minorities and Women in Qing Criminal Justice, Xingbie, zongjiao, zhongzu, jieji yu Zhongguo chuantong sifa [Gender, Religion, Ethnicity, Class and Chinese Traditional Law] (Lau Nap-yin ed.), Taibei, Academia Sincia, Philology Research Institute, 2013, pp. 257-292. 
Ideologically, imposing harsh sentences and profiling bare sticks posed dilemmas, for county magistrates who operated within the confines of the rigidly bureaucratized structure of judicial and sentencing review. The article argues that county magistrates utilized case records to present sympathetic representations of rural poverty and despair that was at odds with the imperial denunciations of violent crime. Rooted in the longstanding judicial ethos to seek leniency and save life, hallmarks of Chinese criminal justice for centuries, these emotional depictions sent a clear message to the central authorities that economic conditions, rather than the moral failings of bare sticks, played an important role in undermining familial stability and social order.

A $\mathrm{t}$ the peak of its power in the eighteenth century the Qing Empire had equaled or surpassed all previous Chinese dynasties in terms of population growth, economic prosperity, and territorial expanse. In stark contrast to the humiliating losses to foreign powers and the devastating rebellions of the nineteenth century, scholars have long considered the eighteenth century a 'flourishing age'.2 Peace and prosperity were the hallmarks of the era, but on closer examination, this pivotal period witnessed both the full grandeur and the ineludible limits of premodern Chinese political, social, and economic institutions. Varying across time and space, the inexorable influence of economic commercialization and population expansion rippled through the vast empire and transformed society. The results of these powerful forces for change were often mixed. Along with the benefits of unprecedented economic and demographic growth came ethnic strife, sexual assaults, violent land disputes, a sorcery scare, and sectarian rebellion that scarred the eighteenth-century social landscape. ${ }^{3}$ Seeking to stem a troubling decline in social order in its Chinese domains, ${ }^{4}$ the Qing court launched a far-reaching, but illconceived crackdown on violent crime. At the forefront of the drive was legislation that mandated harsher penalties, including capital punishment, for crimes when the offenses were committed by 'bare sticks' (guanggun 光棍), a common term for the rootless underclass of unmarried males who were considered crime-prone troublemakers. While Chinese law had a long history of differential punishments based on kinship and gender, bare-stick substatutes effectively defined a new class of criminals who were subject to more extreme penalties based on their social identity.

Embracing a strategy to suppress crime that combined 'criminal profiling' with the presumed deterrent power of capital punishment, Qing emperors presented serious practical and ideological challenges to the judicial bureaucracy. Practically, the elaborate and time-consuming procedures for the investigation, trial, review, and sentencing of capital crimes that had been the mainstay of Chinese criminal justice since the Ming dynasty (1368-1644) remained in place. Increasing the number of capital crimes without allotting additional resources or personnel threatened to

The traditional term in Chinese, shengshi, (盛世), usually translated as 'flourishing age', has normally been reserved for exceptional periods of political, cultural and economic development.

3 The literature on these topics has been prodigious. For ethnic conflicts see Dai (2009). For sexual assaults and rape see Sommer (2000) and Theiss (2004). For violent disputes over property rights see Buoye (2000). For the sorcery scare, see Kuhn (1990). For sectarian rebellions, see Wang (2011).

4 The Qing rulers were Manchurians and their multi-ethnic empire include vast territories that were predominantly Tibetan, Mongolian, and Turkic. These domains were ruled differently than the more populous Han Chinese provinces. 
swamp the criminal justice system, which was already showing signs of strain. Ideologically, imposing harsh sentences and profiling bare sticks also posed political, moral, and cognitive dilemmas, particularly for county magistrates (zhixian 知縣) who dealt firsthand with violent crime and accused criminals. As a review of several exemplary capital case records reveals, reports of capital crimes by county magistrates sometimes presented evocative narratives that were at odds with the assumptions underlying the bare-stick legislation. These somewhat sympathetic representations of rural poverty and despair were, no doubt, rooted in the longstanding judicial ethos to seek leniency and save life that had been the hallmarks of Chinese criminal justice for centuries. ${ }^{5}$ In the midst of a growing concern over the rise in violent crime, these emotional depictions sent a clear message that economic conditions played an important role in undermining familial stability and social order.

\section{REPORTS OF CAPITAL CRIMES}

The review of capital cases varied over time, but the long-term trend was toward greater bureaucratization and centralized control in the prosecution and sentencing of capital crimes. In the Qing dynasty (1644-1911) capital cases were initially investigated and tried at the county level, and subsequently underwent automatic retrial and review at the prefectural, provincial and central government levels, culminating in the emperor's verdict. The judicial review established culpability, cited applicable statutes and assigned specific punishments in strict adherence to the code. Judicial review required straightforward accounts of the essential elements of the crime, forensic evidence, and testimony from the accused and key witnesses to determine which laws had been violated and what punishments were appropriate. At each succeeding level of review the presiding official provided a separate report and recommendation. Complete case records were voluminous and quite redundant. The district magistrate's initial report was the most extensive and comprehensive. While each of the officials was responsible for the document he submitted, the reports were most likely prepared by a legal expert of his staff. Most Qing officials were generalists who had no formal legal training. It was common for county magistrates to rely on secretaries to compose legal case records. So saying, the magistrate alone was responsible for the accuracy of the report and judicial affairs were carefully scrutinized and evaluated. Concern for his professional future dictated that the county magistrate diligently oversee every aspect of the investigation and reporting of capital crime. Since the case record was subject to automatic review at every level of administration, it was the one document that was guaranteed to receive the scrutiny of a magistrate's highest superiors. While it is unlikely that the emperor personally read every report, Qing emperors were known to comment on controversial or unusual case.

The rhetoric of leniency permeated the Qing judicial system from top to bottom. As the Kangxi emperor (1661-1722) noted in his preface to the revised Qing code in 1678: "I have the utmost feeling for human life, especially for that of my people; and where at all possible, I am unwilling to impose the death penalty." Quoted in Alabaster (1936, p. 427). Huang Liuhong, author of a widely circulated seventeenth-century administrative handbook for county magistrates stated: "The magistrate must always lean on the side of leniency. If there is one iota of reason for the suspect to be exonerated, the magistrate must explore the point to mitigate the punishment.” See Huang (1984, p. 65). 
Reports of capital crimes cannot be fully understood without consideration of the two-tiered structure of judicial and sentencing review as well as the general predilection of magistrates to seek leniency that were hallmarks of Qing criminal justice. The legal requirements of the first round of judicial review required straightforward accounts of the essential elements of the crime, forensic evidence, and testimony from the accused and key witnesses that were necessary to determine which laws had been violated and what punishments were appropriate. Influenced by ideological values of benevolence and paternalism, magistrates interspersed case records with understated observations on the individuals involved in the crime that suggested their psychological states, motivations, and moral character. These observations could be used to mitigate final sentencing at the autumn assizes. Accused killers were often depicted as otherwise decent people under duress in extraordinary circumstances who inadvertently caused a death. In my opinion, these depictions were meant to obtain leniency for the vast majority of capital criminals who were sentenced to imprisonment pending final sentencing at the annual autumn assizes (jianhou qiuhou chujue 監候秋後處決)..

For nearly two decade historians have been mining judicial archives, especially the routine memorials of the Board of Punishments (xingke tiben, 刑科題本) at the Number One Historical Archives in Beijing, to expand our understanding of Qing social, economic, and legal history. My own research on violent disputes over property rights relied on capital case records to reconstruct the everyday struggles of rural society. Sampled at roughly five intervals from a collection of nearly 56,000 case records for homicides related to disputes over land or debts for the Qianlong reign, I looked at over 13,000 reports for all of China. From that sample I read 2,152 cases from Guangdong, Shandong, and Sichuan, which included disputes over debts and land. From that sample I focused exclusively on homicides related to disputes over specific property rights issues ${ }^{6}$ in three provinces : Guangdong (480 cases), Shandong (25 cases), and Sichuan (125 cases). While the number of extant documents as well as the number of cases used in my study is not insignificant, in order to get a broader perspective on violent crime during the Qianlong reign (1736-1795) one would need to examine two additional collections of capital cases "blows and affrays" (dou'ou 斗毆) and "marriage and illicit sex" (hunyin jianqing 婚姻茹情) that together contain about twice as many cases. Suffice to say, that the extant documentation of violent crimes for the six decades of the Qianlong reign is voluminous.

My current research concerns extreme crimes involving multiple homicides, brutal killings, intra-family killings, inter-ethnic violence, adulterous wives killing their husbands, and other capital crimes that violated cherished social norms, to ascertain the limits of leniency in judicial practice and the eighteenth-century crisis of Chinese criminal justice. Despite the common Western stereotype of Chinese justice as capricious, corrupt, and cruel, capital case records reveal that county magistrates carefully examined the facts and applied the law in capital investigations. ${ }^{7}$ After reading thousands of case records written by county magistrates from hundreds of different jurisdictions from across the length and breadth of China, one cannot help

$6 \quad$ I distinguished two categories of disputes: contractual, which included rent defaults, evictions, and redemptions of conditional sales, and non-contractual, which included boundary and water rights.

7 For an example of statutory pardons, see Buoye (2007). 
but be struck with the consistency, clarity, and competence with which magistrates investigated, adjudicated, and reported capital crimes.

County magistrates had a range of responsibilities from education to tax collection, but the investigation, trial, and reporting of capital crime were arguably the most complicated, onerous, and carefully monitored of all their duties. The successful investigation and trial of a capital crime required the supervision of a variety of subordinates, including constables to arrest suspects and gather evidence, coroners to examine wounds and perform autopsies, and legal secretaries to research the law and compile reports. Procedurally, the county magistrate's direct responsibilities were limited to examining the evidence, determining culpability, identifying the appropriate law, and recommending a specific sentence. When done properly, capital case records were masterpieces of bureaucratic efficiency and thankfully, cornucopias of legal, social, and economic history for modern researchers. Interestingly, within the confines of the reports of capital crime there existed a subtle and reliable channel of communication between a county magistrate and his superiors, including the emperor. Every county magistrate knew for certain that his superiors would glance at if not carefully peruse these reports. Given the complexity of the sentencing procedures, official scrutiny of trial records could continue for years after a crime had occurred. ${ }^{8}$ I argue here that given the certainty that their reports would receive repeated review, some county magistrates availed themselves of this "channel of communication" to address, however subtly or indirectly, the prevailing views of the sources of violent crime and social disorder and the dire circumstances of the rural poor.

\section{EIGHTEENTH-CENTURY CHINESE SOCIETY}

While emphasis may vary, historians generally agree that the transformative impact of demographic pressures, environmental degradation, political corruption, and social instability were readily apparent in the latter half of the eighteenth century. Noting the similarities to the classical symptoms of 'dynastic decline', Philip Kuhn and Susan Mann have examined the interconnections between the "overproduction of literate men" and "rampant" corruption, and rising demographic pressures and

$8 \quad$ The ultimate fate of individuals who were imprisoned awaiting final sentencing at the autumn assizes in the eighteenth century was uncertain. By law if capital punishment was deferred for three consecutive years after the initial review at the autumn assizes, the death sentence could be reduced to banishment. In practice archival records clearly indicate that the three year deadline was often exceeded. Further research on this issue is needed but mandatory investigations of deaths of prisoners awaiting final sentences for capital crimes reveal that some individuals remained in local jails for over three years. The most egregious case I have encountered was an individual who died of illness in a county gaol after his capital sentence had been deferred at 24 consecutive annual meetings of the autumn assizes.

9 Beginning in the Song dynasty (960-1279) civil service examination was the normal route to government service. The content of the exams was based on Confucian classics that educated male elites began studying in childhood. In this sense the overwhelming majority of Chinese officials could be consider literate men or scholars. Exams were held at the local, provincial, and national levels but only the national level degree holders were guaranteed government employment. While the Chinese elite comprised only $2 \%$ of the population, limits on the number of degrees granted and the unwillingness of Qing rulers to expand the size of government meant that the absolute number of highly educated elites who could not find government employment was also on the rise during the 
an increasingly commercialized economy. ${ }^{10}$ Similarly, William Rowe has cited the "sudden and wrenching population growth", "unprecedented geographical and social mobility" and "rapid commercialization and monetization of the economy" as the important trends of that transformed eighteenth-century China. ${ }^{11}$ While agreeing that the "single most important structural change was explosive population growth", Wang Wensheng has also blamed the large scale social unrest in the Qianlong reign (1736-1795) on the growing gap between "state ambitions and state capacities" and the failure to increase the "political resources allotted for local administration". ${ }^{12}$ More people and more territory were historical measures of dynastic prosperity, but Qing emperors and government officials alike knew that they also faced serious administrative challenges. As one of the most famous scholar officials of this era, Hong Liangji wrote candidly and presciently about the problems of overpopulation, political corruption, and the need to reform local administration. Famous for citing the potential catastrophic impact of unrestrained population growth, Hong also complained about poor channels of communication between officials as well as the throne and the overall decline of local administration. ${ }^{13}$ Hong's frank criticism of the dynasty earned him a suspended death sentence and banishment to Ili in Xinjiang. Not surprisingly, no other officials ever matched Hong's outspokenness, and there were few substantive institutional reforms in China until the middle of the nineteenth century.

The sorcery scare of 1768 , which Philip Kuhn has written about so insightfully, provides a powerful illustration of the bureaucratic politics that impinged on Qing criminal justice. ${ }^{14}$ In many ways the prosecution of the soulstealing ${ }^{15}$ was emblematic of the social and economic milieu of the eighteenth century. "Dropping out of the settled occupations into vagrancy and begging", which Kuhn calls "downward migration", was the backdrop for the sorcery scares. The potential for social panic was serious and the incidents, which often involved the cutting of victims' queues, had political overtones that drew the attention of the Qianlong emperor. When provincial judicial officials, who initially did not share Qianlong's same sense of trepidation, failed to placate his concerns, the emperor personally intervened and transformed the

eighteenth century. See Elman (2000) for a description of the increasingly competitive nature of the civil service examinations in the Qing.

10 See Mann, Kuhn (1976, pp. 107-163).

11 Rowe (2002, pp. 473-562 p. 473). Rowe's essay draws on a wide range of scholarship including the classic English-language studies: Ping-ti (1959) and Lin (1990). For an in-depth economic analysis of the period, see Myers, Wang, (2002), pp. 570-572.

12 See Wang (2011). While Wang agrees with much of the received wisdom on the topic, he stresses the Qianlong's "overambitious attempts to push empire-building beyond a supportable limit" as an important factor in undermining the government's ability to maintain social order.

13 See Liu (1999, pp. 172-178). Some Western scholars have dubbed Hong "China's Malthus" though Hong wrote some five years earlier.

14 Kuhn (1990). Briefly, the sorcery scare was based on the popular belief that the human soul could be separated from the body and that the individual who obtained the soul could use its force. Alleged incidents of soulstealing, particularly when the victims were male children, led to violent attacks on the accused perpetrators.

15 Kuhn (1990, pp. 26-27). The process involved reciting incantations over some physical entity that had been removed from the victim. Quite often this was hair from the individual's queue, the politically significant ponytail worn by Chinese men. The ruling Manchu dynasty had decreed the wearing of the queue by all Han Chinese males under penalty of death. 
scope and intensity of the official campaign to uncover soulstealing. In this superb work of social history, Kuhn masterfully explores the deep complexities of these events. Most relevant to this study is the reaction of provincial judicial officials to imperial intervention. Based on their initial reactions, most provincial officials likely saw soulstealing as a troublesome folk superstition. But once the emperor intervened directly and forcefully, the previously skeptical suddenly began turning up culprits. Unlike the more pervasive and enduring threat of the generic bare sticks, the sorcery scare of 1768 was a protracted affair that drew the intense and direct scrutiny of the emperor. the sorcery scare illustrated an important point: from the lofty perch of Beijing a variety of mundane and extraordinary political and psychological concerns could easily distort the imperial perception of eighteenth-century grass roots society.

Nowhere were the contradictory crosscurrents of the eighteenth century more apparent than in the adjudication of capital crimes. The cautious and appropriate application of punishments, particularly in capital cases, had been a consistent theme in Chinese legal commentaries for over two millennia. ${ }^{16}$ In practice, a deep regard for human life was manifested in the special procedures for handling death penalty cases in Chinese law. Procedures for reviewing capital cases varied over time, but the long-term trend was toward greater bureaucratization and centralized control in the adjudication and sentencing of capital crimes and this trend reached its apex in the Qing dynasty. The reluctance to expand the government despite a doubling of population meant that the multi-tiered and repetitive reviews of capital crimes and most death sentences greatly exacerbated what was an enormous administrative burden for the Qing bureaucracy.

\section{CHINESE LEGAL HERITAGE}

For a variety of complex reasons - cultural, intellectual, political and economic - Western observers frequently have misunderstood or misrepresented Chinese legal heritage and judicial practice, but the great Chinese dynasties could not have obtained the vast territorial expanses, elaborate administrative structures, and vibrant commercial economies without the existence of well-established legal institutions. The Qing dynasty was no different than its illustrious predecessors. Despite their alien origins, the Manchu conquerors readily embraced the Chinese legal heritage. Even more impressively, in 1670 the Kangxi Emperor (1661-1722) espoused Confucian principles and endorsed the efficacy of law in his Sacred Edict. Consisting of 16 terse maxims, the Sacred Edict has been called "a summation of Confucian moral values" 17 and the "most concise and authoritative statement of Confucian ideology". ${ }^{18}$ Meant to be read aloud in every village and town in the empire, the Sacred Edict envisioned a well-ordered society of filial subjects who obeyed the

16 Noting the irreversibility of capital punishment, the oldest extant Chinese document that discussed the administration of justice, the Kang Gao (康誥) (dating from the early 1046-771 BCE), strongly admonished rulers to apply physical punishment judiciously and urged the substitution of fines for corporeal punishments in doubtful cases. The Lü xing, (呂刑) (dating from the Warring States period c. 475-221 BCE) also urged caution and mercy in the use of physical punishments. See MacCormack (1986-1987, pp. 35-47).

17 Spence $(1999$, p. 60).

18 Mair (1985, p. 325). 
law, avoided disputes, extirpated heresy, paid taxes, and peacefully engaged in agriculture. Interestingly, law was an integral component of this Confucian-cloaked pronunciamento. The eighth maxim, "Explain the laws to warn the ignorant and obstinate", endorsed law as a tool of government and succinctly encapsulated elite attitudes toward the source of criminal behavior - ignorance and obstinacy. ${ }^{19}$

The implications of the eighth maxim for a Confucian-trained official with experience in criminal justice would have been abundantly clear. Ignorance versus obstinacy established a simple dichotomy. Optimistically, the maxim implied that propagating the law eliminated ignorance and reduced crime. Furthermore, if criminal behavior was remedial through education, leniency was justified. Demonstrating the premise that dissemination of the legal knowledge went hand-in-hand with the propagation of Confucian ideals, one of the earliest commentaries on the Sacred Edict, published in 1679, explained all sixteen maxims with reference to specific laws and "examples of applicable legal guidelines". ${ }^{20}$ Targeting popular ignorance of the law with public lectures clearly indicated both a belief in the efficacy of law and the responsibility of social elites to transmit legal knowledge to the illiterate masses. As Janet Theiss notes in her study of the eighteenth-century chastity cult, adopting the approach of "teaching and cultivation" (jiaoyang 教養) of the people, or the "transformation of customs through education" (jiaohu 教化), was an important component of imperial ambitions to transform society. ${ }^{21}$

However, what if crime did not abate despite the best efforts to educate ? Following the ignorance versus obstinacy dichotomy, Qing officials could assume it must have been due to obstinacy and obstinate criminals clearly deserved punishment. While the tendency to seek leniency and "save life" were cornerstones of Chinese legal philosophy that mitigated severity, there is plenty of evidence that Chinese magistrates did not shy away from using harsh punishments when criminal acts were deemed exceedingly heinous or wanton. What was distinctive about the eighteenth century was the legislative turn that resorted to the secernment of bare sticks.

\section{THE LEGISLATIVE TURN}

The Qing law code was a living document that underwent revisions to address the changing needs of Chinese society. Officially, the emperor was the chief law maker and some laws originated in imperial decrees, but normally the emperor "approved or rejected recommendations made to him in memorials submitted by officials charged with judicial and legislative authority". ${ }^{22}$ Zheng Qin, an authority on the Qing code, has noted "the extraordinary enthusiasm and dedication of top imperial authorities

19 Perpetrators of homicides, regardless of the circumstances, were invariably described as "ignorant of the law" and frequently labeled "obstinate". The retention of these formulaic references, even when capital crime reports underwent extensive streamlining during the latter half of the eighteenth century, indicates the importance of this understanding of origins of criminal behavior.

20 Mair (1985, p. 329).

21 Theiss (2004, p. 35). Janet Theiss notes that "The concept of jiaohua was an old staple of Confucian statecraft discourse, but it acquired a distinctly paternalistic and bureaucratic cast in the eighteenth century as emperors and officials basking in the peace, prosperity, and imperial might of the High Qing formulated new ambitions for the state's role in society".

22 Edwards (2003, p. 181). 
toward their lawmaking enterprise", which he argues indicated "the importance of the law to Qing rulers." ${ }^{23}$ In fact, a major revision of the code, the third since the Qing dynasty was founded in 1644, was completed in 1740. The new code contained the original 436 statutes, most of which were unchanged, and 1,049 revised or newly added substatutes. ${ }^{24}$ Knowledge of these revisions was crucial because magistrates were required "to cite the statues and substatutes upon which they relied in deciding a case to ensure that the result conformed to the statutory purpose". ${ }^{25}$ Any historian familiar with Qing capital case records can readily attest to the importance of citing specific statutes for every crime reported. ${ }^{26}$ Tellingly, the new substatutes were guideposts to the sources of tension in eighteenth-century society. For example, addressing property rights in land, the revised code included a range of substatutes that included the criminalization of rent defaults and the clarification of terms of conditional sales. ${ }^{27}$ Given China's rich legal heritage, it comes as no surprise that eighteenth-century emperors resorted to legislation to define property rights and to combat the rise in violent crime. What was surprising was the number and specificity of new substatutes. For example, during the Ming dynasty (1368-1644) there was one statute and two substatutes in the section on robbery (qiangdao 強盜), during the Qing dynasty (1644-1911) there was still only one statute but there were an additional 49 substatutes, "most of which dated from the 17th and 18th centuries". ${ }^{28}$ Similarly, fostering and protecting female chastity was also codified during the eighteenth century. Legislation on sexual assault provides another very sobering example. Fortunately, we have two in-depth studies of sexual assault for eighteenthcentury China, by Matthew Sommer and Janet Theiss. ${ }^{29}$ Both scholars agree that that anxiety at the highest levels of government was behind the proliferation of new legislation that increased penalties for sexual assault and related crimes. Duly noting the substatutes related to illicit sex promulgated during the Yongzheng and Qianlong reigns - "illegalities in the contracting of marriages (some twenty-five substatutes), homicides arising out of sexual assaults, adultery and prostitution (altogether over forty substatutes), and causing a woman to commit suicide through improper behavior (some twenty-five substatutes)" - Theiss argues that "collectively these myriad new substatutes reflected widespread anxiety among mid-Qing elites". ${ }^{30}$ Similarly, in his discussion of rape laws Sommer notes "a plethora of new measures aimed to suppress the 'rootless rascals' ${ }^{31}$ (guang gun) who were now imagined as

23 Zhen (1995, p. 332).

24 Ibid. The final published revision of the code in 1870 contained a total of 1892 substatutes. To date there is no complete translation of the substatutes in English although the unchanging statutes have been translated in to French and English. Scholars only familiar with the statutes, many of which remained unchanged in successive dynasties spanning several centuries, have mistakenly gotten the impression that Chinese law was "unchanging".

25 Edwards (2003, p. 183).

26 Indeed, Jerome Bourgon has called this principle of legality "one of the major institutional inventions of Chinese civilization." See Bourgon (2012, p. 171).

27 Buoye (2000, p. 96).

28 Meijer (1991, p. 24).

29 Sommer (2000); Theiss (2004).

30 Theiss (2004, p. 47).

31 Sommer prefers to translate guanggun as "rootless rascal". 
sexual predators". ${ }^{32}$ Whether it was myriad or plethora, this legislation disturbingly reflected the tenor of the times. For example, a substatute was added in 1788 (QL53) and later revised in 1809 (JQ14) under statute against Plotting to Kill Another (282) that increased the penalty to "immediate" decapitation ${ }^{33}$ for the leader of the plot to kill when the victim was a child aged ten or younger. If there was extortion or sexual abuse, the penalty was increased to decapitation with exposure of the head in public. ${ }^{34}$ The fact that a law specifically addressing the premeditated killing of children under ten years of age was deemed necessary was a frightening indication of the types of violent acts that were perpetrated in Qing China. By the eighteenth century the defining characteristics of a bare stick, violent coercion or physical intimidation, had become firmly imbedded in Qing legal parlance and political discourse. Interestingly, both the Qianlong and Yongzheng emperors framed the problem of violent crime in terms of the moral failings of bare sticks and responded by promoting conservative moral values and promulgating harsher laws that specifically targeted bare sticks. The combination of moral exhortation, condemnatory rhetoric, and harsh sentencing was readily apparent in the proliferation of new substatutes promulgated during the eighteenth century.

\section{BARE STICKS}

In the eighteenth-century judicial discourse the term bare stick became synonymous with a variety of serious crimes, but the use of the term to describe rootless males had been part of the Chinese vernacular since the Song dynasty. ${ }^{35}$ By the Ming dynasty the terms "bare sticks" and “urban toughs" (lahu 啦唬) were used to describe members of criminal gangs involved in robbery, intimidation, and prostitution in the Beijing area. ${ }^{36}$ The term also appears in the popular Ming novel The Plum in the Golden Vase, which describes an incident in which bare sticks induce the son of an Imperial Commissioner to join them in visiting a brothel. When the bare sticks later attempt to extort money from the hapless youth he seeks the help of the local magistrate who orders a beating for the "detestable" bare sticks. ${ }^{37}$ According to Qing literary sources, anyone engaged in racketeering, swindling, black mail, or other "scoundrelly activities were generally known as bare sticks." 38 Legally, the term first appeared in the Ming code. ${ }^{39}$ The Ming code specifically labeled bare sticks: demobilized soldiers, the homeless, and other marginalized people "not

\footnotetext{
32 Sommer (2000, p. 10).

33 The sentence of "immediate" decapitation could not be carried out until after a full judicial review.

34 All citations for substatutes come from the Xue Yongsheng, Duli Cunyi on line at [http ://www.terada. law.kyoto-u.ac.jp/dlcy/index.htm] (accessed May 23, 2013).

35 Chen (1993, p. 272).

36 Robinson (2001, p. 49). Robinson includes both bare sticks and urban toughs under the heading of "men of violence", criminal gangs who were active in Beijing and its satellite cities in the mid-Ming.

37 Sheng (1993, pp. 269-271).

38 Chen (1993, p. 273).

39 For example, the term appears frequently in the Huangming tiaofa shilei zuan 《皇明條法事類纂》 vol. 34 Xingbu lei (刑部類). I am indebted to my colleagues, Jiang Yonglin and Wu Yanhong, who explained the significance of the Ming statutes.
} 
engaged in honest work" (buwu zhengye 不務正業) who used force and intimidation to swindle honest people. Whatever the sociological origins of bare sticks, the term had become common judicial jargon in the Ming code in $1443,{ }^{40}$ but there was no specific offense defined as the bare stick substatute until the Qing dynasty.

Judicial officials throughout the realm must have known how seriously the emperors viewed the problem of bare sticks. During the Qing dynasty the scope of bare stick crimes was expanded to include illegal activities of yamen personnel, pettifogging, false accusation, fraud, opening graves, hoarding, tax resistance, witchcraft, and other crimes. ${ }^{41}$ In 1705 the Kangxi emperor (1661-1722) excluded bare sticks from imperial pardons and in 1729 the Yongzheng emperor (1723-1735) commended officials who cracked down on bare sticks.

\section{BARE STICKS IN THE LAW}

While there was nothing equivalent to a modern legal definition that strictly delineated who was a bare stick, substatute $273.7,{ }^{42}$ under the statute "Using Intimidation to Obtain Property," was commonly referred to as the "bare stick substatute" (guanggun li光棍例). Interestingly, this substatute lists a range of crimes involving violent extortion, intimidation, beating, killing and false accusations that should be punished more severely "if the circumstances are serious" and bare sticks were "truly to blame" ${ }^{43}$ The only other term used to refer to the perpetrators is another general term usually translated as scoundrel (e'gun惡棍). Apparently, it was assumed that judicial officials would know bare sticks when they saw them. As the table below indicates, the bare stick substatute was cited in another sixteen substatutes. In fifteen of those substatutes the bare sticks substatute was to increase the severity of punishments. Some of these substatutes were already in versions of the code compiled during the Shunzhi (1644-1661) or Kangxi (1662-1722), but most were added or amended during the Yongzheng (1723-1735) and Qianlong (17361795) reigns.

Laws That Cite the Bare Stick Substatute ${ }^{44}$ :

Law

Substatutes

- Monopolizing Markets (154)

- Pushing Honorable Persons too Far and Causing Them to Revolt (210) 1

- Wrongful Taking in the Daytime (268) 3

- Using Intimidation to Obtain Property (273) 3

- Kidnapping Persons and Selling the Person Kidnapped (275) 1

$\overline{40 \quad \text { Zhang (2008). }}$

41 Zhang (2008, pp. 156-158).

42 Numbering of laws and substatutes follows Xue (1970).

43 A translation of the entire substatute can be found in Sommer (2000, pp. 327-328).

44 The substatutes in this table include the bare stick substatute 273.7 , and all other substatutes that cite the bare stick substatute to assess punishments. The term bare stick appears elsewhere in the Qing code but the substatute is not cited. 
- Engaging in an Affray and Killing or Intentionally Killing Another (290)

- Striking an Imperial Emissary or the Head Official in One's Own Office (306) 1

- Fornication (366)

- Persons Sentenced to Penal Servitude or Exile who Run Away (390) 1

- Citing Laws and Orders in Deciding Cases (415)

While the link between bare sticks and sexual crime is warranted, given that four substatutes under the law against "Fornication" were sentenced under the bare stick substitute, perpetrators of crimes sentenced under the substatute were not merely rootless male sexual predators. For example, substatute 154.6, under the law against "Monopolizing Markets", which concerns crimes committed by employees of the Imperial Household Department or their relatives, imperial princes, eunuchs, officials or their relatives - none of whom would be considered downwardly mobile males - cited the bare sticks substatute to determine the punishments. ${ }^{45}$ Other crimes, such as Pushing Honorable Persons too Far and Causing Them to Revolt (210.2), addressed a variety of illegal forms of collective actions, such as tax resistance or monopolizing markets as well as instigating lawsuits or interfering with local civil service examinations. The bare stick substatute was cited to authorize immediate decapitation for the leaders of these actions when the act involved more than forty or fifty people. ${ }^{46}$ Similarly, Wrongful Taking in the Daytime (268.23) specifically named bandit groups active in four provinces and cited the bare sticks substatute to punish the leaders of bands of five or more. Fornication has the most substatutes citing the bare stick substatute but here too the picture was complicated. Appallingly, two of the four substatutes under Fornication involved assaults on minors. The substatutes under Fornication that applied the bare stick substatute included gang rapes (366.2), kidnapping and sodomizing boys (366.3), raping and causing the death of young girls under twelve or enticing girls over the age of ten into sex (366.4) and (366.9) rapes committed by lamas and monks. Suffice to say that although sexual crimes bulked large in official denunciations of bare sticks, "bare stick crimes" included a wide variety of violent crimes that might be undertaken individually or collectively. Depending on the crime, bare stick would be better translated as hoodlum, rapist, swindler, extortionist, or gangster.

Space does not permit detailed discussion of every crime, but the common denominator of "bare stick crimes" does not appear to be the social status of the perpetrators. On the contrary, these crimes appear to be related, albeit in very different ways, to the social side-effects of an increasingly complex commercialized economy and a highly mobile population. As grass roots officials responsible for day-to-day administration, county magistrates were well aware that the economic expansion, population growth, and increasing commercialization of the eighteenth century had serious social repercussions. Similarly, regional variation in economic development was significant. Time and place were critically important to understanding connections between social conflict and economic change.

45 According to Xue Yunsheng, the law originated in the Ming dynasty, but the death penalty was not invoked then. Available at [http://www.terada.law.kyoto-u.ac.jp/dlcy/index.htm] (accessed May 23, 2013).

46 Ibid. 


\section{REGIONAL VARIATION IN CRIME}

As homicides related to violent disputes over property rights have revealed significant regional variation in the overall levels of violence as well as the social and economic status of disputants. ${ }^{47}$ Given that homicides related to property rights were a transitional phenomenon related to induced demand for changes in property rights, it makes sense that provinces experiencing economic change at different times would also exhibit different patterns of violence. For the six sample years used to compare regional variation in homicide related to property right disputes, Shandong had far fewer homicides (25 cases), than Guangdong (150) and Sichuan (125). Interestingly, although Shandong had fewer cases overall, the individuals involved in violent disputes there more closely fit the rootless male profile. ${ }^{48}$

Information gleaned from capital case records reveals that the condition of rural employment in Shandong was clearly inferior to that of either Guangdong or Sichuan. Farms were generally larger in north China and productivity lower, requiring closer supervision and control of laborers and tenants. ${ }^{49}$ Qualitative analysis of Shandong disputes in my earlier study revealed that individuals involved in violence were often quite poor and their employment was tenuous. Landlords hired managers who wielded great power over tenants and hired laborers. Evidence from homicide reports reveals that these managers readily dismissed tenants and laborers for poor performance and that the managers themselves could be fired at the whim of the landowner. Tenant farmers and hired laborers also had little personal freedom and economic independence. Many lived in their landlords' home and relied on their landlords for draught animals, plows, and seeds. ${ }^{50}$ While a range of variables might explain the lower incidence of violence in Shandong, capital case records vividly reveal that individuals involved in disputes in Shandong were worse off economically than their counterparts in Sichuan and Guangdong.

Case records of capital crimes from Shandong frequently reveal tantalizing glimpses into life in eighteenth-century rural society. Consider the case involving Jiang Hansan, Fan Wuyuan, Li Jing, and Wang Yin, who were all tenants on Chen Gengwu's land. ${ }^{51}$ What makes this case interesting is the migrant status of the tenants: Jiang Hansan was from Guancheng county, Fan Wuyuan was from Dingtao county, and Li Jing was from Puzhou county. Only Wang Ying was from Caoxian county, where the dispute occurred. This was quite different from Guangdong where tenants and landlords were almost always from the same county and many tenants, as former owners of the land they rented, had deep personal and customary ties to the land that they tilled. (Interestingly, the alacrity with which Jiang's fellow tenants came to his aid when a violent dispute arose with a neighboring landowner also

\footnotetext{
See Buoye (2000).

48 Buoye (2000, Chapter six).

49 Li (1988, pp. 33-34).

50 Yang (1988, p. 54).

51 Xingke Tiben, tudi zhaiwu lei (刑科題本土地債務類hereafter XKTB), 3252, Qianlong 45.09.26. The archival source for the cases is the Number One Historical Archive in Beijing. The documents are Board of Punishments routine memorials (xingke tiben) from the category of land and debt (tudi zhaiwu lei), 3252 is the bundle number and the document was compiled on the twenty-sixth day of the ninth month in the forty fifth year of the Qianlong reign (October 23, 1780).
} 
suggests a degree of class solidarity among hired laborers that was not found in Sichuan or Guangdong). The absence of personal ties to the land that they worked along with the fact that Shandong landlords often supplied the necessary capital, such as seeds and tools, may explain why tenants were treated like hired laborers in Shandong. This proletarianization of agricultural labor often meant that Shandong tenants were normally judged solely on performance and could be dismissed for 'laziness'. In Shandong, deadly confrontations over property rights were rare, but what property-related violence did occur was clearly the domain of the desperately poor who had been left behind in the economic expansion of the eighteenth century.

\section{THE LUCKLESS TENANT 52}

Wang Chen's fate poignantly illustrated the precarious nature of life in rural Shandong. Wang leased $24 \mathrm{mu}$ (畆) of land from Guo Gengyuan in Wenshang county. Guo Gengyuan lived some distance from the field, so he entrusted Cheng Zhao with the management of the land. On the morning of 13 June $1749,{ }^{53}$ it rained, and Wang Chen decided it was a good time to plant soy beans. He asked Cheng for the seeds. Unexpectedly, Cheng not only refused to provide the seeds, but he also accused Wang of being lazy and demanded that he return the land immediately. In his subsequent testimony, Cheng claimed that Wang had done a poor job of planting the sorghum and millet. Cheng feared that the landlord, Guo Gengyuan, would criticize him for Wang's poor work. Wang Chen suggested that they wait until after the autumn harvest before he relinquished the land. Unfortunately, Cheng not only rejected this request but also accused Wang of dishonesty. Cheng later claimed that he was only trying to frighten Wang in order to motivate him to work harder and did not really mean to evict Wang. Wang, however, took this threat quite seriously and replied: "If you demand that I return this land now, is it not the same as killing my family?" Wang Chen died from the injuries suffered in the ensuing struggle with Cheng Zhao.

To the casual observer this case might appear to be an unfortunate but unexceptional example of manslaughter. An experienced official reading this case record however would no doubt take notice of evocative statements such as: "If you demand that I return this land now, is it not the same as killing my family?" Declarations like these were not typical in case reports. Both the statement from the manager and his tenant's entreaty indicated the depth of despair and hopelessness of the rural poor in eighteenth-century Shandong. Wang was clearly a pitiful individual. Threatened with the loss of his livelihood he equated the loss of his tenancy to the death of his family. In a highly structured and otherwise unemotional recitation of the facts of the case, this statement had an immediate and jarring impact. The prominent positioning of such a powerful metaphor in an otherwise straightforward account must have been deliberate. In my opinion, by prominently quoting Wang's desperate plea, the magistrate was intentionally sending a powerful message to his superiors. Poverty was killing the family in Shandong. This was how a bare stick was created.

52 XKTB 0714, QL 15.4.17.

53 Dates in documents are given in reign year and lunar month. 13 June 1749, is QL 14.4.29, meaning the twenty ninth day of the fourth month in the fourteenth year of the Qianlong reign. 


\section{THE HAPLESS GAMBLER ${ }^{54}$}

Of course, many peasants lost their land, but they managed to survive as agricultural contract workers. Perhaps employment in the master's household could provide a surrogate family for the landless laborer. Consider the case of Huang Bang. At forty-two sui (歲), ${ }^{55}$ Huang, who had no immediate family, was hired as a contract worker in Ming Keyi's home on 23 December 1748. Huang had lost 2000 wen (文) gambling with three of his co-workers, Li Hai, Ming Kuijiu, and Yang Seng, all of whom tried repeatedly to collect the debt. In 1749, after the wheat harvest Huang's workmates once again dunned him. Huang went to his employer, Ming Keyi, and asked him for some grain in advance of his wages so that he could pay his debts, but Ming, "unaware that it was a gambling debt", ${ }^{56}$ refused. Huang became angry and cursed Ming, complaining that he had no face. When Huang finally received his wages, 500 wen, he used them to pay part of his debt.

On 21 April 1749, Ming Kuijiu informed Ming Keyi (same surname but not related) that Huang had gambling debts. Huang overheard Ming Keyi advise Ming Kuijiu to wait until after the harvest to dun Huang. Ming Keyi further advised that if Huang could not pay in full, Ming Kuijiu should beat him and take him to the officials. About six months later, Huang overheard Ming Keyi and Yang Seng chatting about the gambling debt. Once again the boss repeated his advice to beat Huang and take him to the officials. At this point Huang became desperate. Huang testified that he knew Ming Keyi would "expel him after his work was completed" and that Ming Keyi had ordered his co-workers to demand money, beat him, and take him to court.

When Huang realized that he would lose his livelihood he "harbored resentment all the more deeply," and "murderous thoughts arose". Knowing that physically he was no match for his boss, he thought about killing Ming's two sons instead. The next day he went to the market to buy poison that he intended to use on himself after he killed the boys. On his way home he bumped into Ming Kuijiu, and they argued loudly. After Ming Kuijiu returned home he informed Ming Keyi, who sought Huang out and confronted him. Huang also threatened to sue Ming Keyi for stirring up trouble for him. Upset and angry, Huang waited until Keyi left the house the next morning. Armed with a wooden mallet, he entered the sleeping quarters of Keyi's two young sons and smashed their skulls.

Ming Keyi later testified that Huang was from a nearby village and worked for a living. According to Ming, Huang's "character had never been good", but he hired him because Huang was a capable farmer. Ming admitted that he hated Huang for gambling and stirring up trouble, and that he had suggested that Kuijiu "sue" Huang (his own testimony omitted reference to beating), but he asserted that the matter of the debt did not concern him. Ming Keyi also emphatically stated that he did not incite Ming Kuijiu to dun Huang. Instead he claimed that he was concerned that there might be trouble if the co-workers privately dunned Huang so it was better to

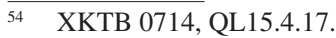

55 Traditionally, Chinese reckoned age as one sui at birth. A newborn is one sui at birth and "turns" two at the start of the second year. In this way an individual who is 42 sui might be 40 or 41 by Western reckoning.

56 Noting that the employer, Ming Keyi was "unaware" that this was a gambling debt, absolves Ming of any connection to the crime of gambling. 
take the matter to court. Finally, Ming explained that he had confronted Huang the day before the killings because Ming Kuijiu told him that Huang was threatening to sue him. Ming could not understand why Huang hated him so much that he killed his two sons.

Not surprisingly, Huang had a different version of events. Huang's testimony emphasized that he was completely dependent on his master, Ming Keyi, for his livelihood. Huang complained that Ming had twice told his workmates to beat him and sue him and that he feared Ming would turn him out of his home. In his final cross examination, Huang stated that he was a poor person who hired out to make his living and relied on his employer to look after him. According to Huang, Ming Keyi twice spoke "wicked words" to his co-workers. He accused Ming of waiting until the harvest was in to turn him out, and of inciting his workmates to turn him in to the local officials. Huang noted that his wages were insufficient and asked rhetorically, "If I lost the master's pay, how could I repay my debts?" Expressing his complete despair, Huang inveighed: "This clearly would put an end to my livelihood and would lead to my death". Thus, he was angry and wanted to kill Ming Keyi. In final effort to obtain leniency, Huang admitted his guilt and declared that he was willing to pay for his crime with his life.

The crime was heinous and brutal, and there was no question that the punishment would be severe. Huang was sentenced to "lingering death" ${ }^{57}$ for the premeditated killing of his master's two sons. There was no hope of leniency in this case, no matter how pathetically Huang was portrayed. Why then would the report include this poignant depiction of a desperately pitiful contract worker? I would argue that the portrayal of Huang was meant to inform or warn higher level officials about the dire social consequences of the abject poverty in Shandong countryside. Chinese society was ideally built on hierarchical relationships that carried mutual obligations. Huang was alone in the world but he still sought honest employment rather than crime. Because he was bereft of family, his employer was his only possible benefactor in times of distress. Huang felt betrayed when his employer not only refused to help him but also aggravated his plight by instigating his workmates to sue him. In his desperation, Huang intentionally killed both of his master's sons. Few crimes were more abominable in Confucian society, yet the county magistrate, rather than revile the killer, presented a nuanced account that explained the depth of Huang's desperation.

\section{THE MAKING OF A BARE STICK ${ }^{58}$}

The case of Kuang Wenqi provided another tragic and barbarous example of the toll that Shandong's grinding poverty was taking on individuals, illustrating the

57 Also translated into English as death by a thousand cuts or death by slicing, lingering death entailed flaying of the limbs, dismemberment, and decapitation. In judicial practice, there were three forms of capital punishment: strangulation, decapitation, and lingering death. Based on the Confucian belief that the body should be returned 'whole' to ones' parents, any mutilation of the body was considered unfilial. (See Feng (1983, p. 358)). Thus, strangulation was considered the least severe punishment because the body remained intact. Lingering death was the most severe form of capital punishment because the body was dismembered. 
slow, agonizing, and dehumanizing descent into rootless poverty. After his father died, Kuang Wenqi was raised by his uncle Kuang Yuxiang and his aunt Ms. Dong, with whom he shared a home. Wenqi was described as "not law-abiding", and his uncle often lectured him. According to neighbors, Ms. Dong was a mean person who never displayed kindness to her nephew. Kuang's aunt was portrayed as a shrew who often interfered in Wenqi's life. When her husband agreed to lend Wenqi money, Ms. Dong intervened to stop him. Wenqi lived modestly and was married, but not happily. Ms. Dong disparaged Wenqi to his wife, causing the couple to fight often. Neighbors testified that Kuang Wenqi had a difficult life and that he blamed his aunt for the deaths of his mother and brother, his marital difficulties, and his dire straits. The magistrate also described Ms. Dong as "harsh" and "too talkative in front of her husband", one of the seven grounds for divorce under Qing law. Suffice to say, the portrayal of Ms. Dong was uniformly unflattering.

In the fall of 1747, while Kuang Wenqi was away trading, his mother and younger brother died. His uncle and aunt had them buried after his maternal uncle arrived to confirm the circumstances of their deaths. When Wenqi returned home he suspected that his aunt had "worn them down" to death and he harbored resentment against his aunt. In February 1748, Kuang sold his wife for 10,000 wen because she followed Ms. Dong's efforts to stir trouble. His uncle borrowed 4000, which he did not repay despite Wenqi's requests. In roughly six months Wenqi had lost his closest living relatives and he had sold his wife. His uncle, the only senior male relative in his life, took advantage of Wenqi's sale of his wife to borrow money which he did not repay.

Alone and with no one to rely on, Wenqi wandered as a vagrant. In his absence Ms. Dong occupied Wenqi's room in their home. On 20 December 1748, Kuang returned home, but Ms. Dong cursed him and refused to let him into the house. He asked his uncle to repay the money he had borrowed but his uncle refused. "Cold and hungry and without a home or kin to support him", Kuang blamed all his troubles on Ms. Dong. The next day he returned to the house with a knife and stabbed Ms. Dong six times. When Ms. Dong's twelve-year-old son saw Wenqi the boy fled, but Wenqi chased him and slashed him with the knife. Returning to the house, Wenqi found Ms. Dong's five-year-old daughter crying and he killed her too. Covered in blood, Kuang immediately turned himself in to the authorities.

Clearly, Kuang Wenqi's crimes were unforgivable. He was sentenced to lingering death for killing three members of the same of family. But despite the viciousness of his crime, the county magistrate managed to evoke sympathy for Wenqi's downward spiral into poverty. While Ms. Dong did not deserve her brutal fate, it was clear from the case record that she cruelly tormented Wenqi. More telling was the language used to describe Wenqi after he sold his wife and wandered the countryside. He roved about "alone and had no one to rely on". Similarly, when Kuang returned home to find that Ms. Dong refused to allow him to enter the courtyard and his uncle cursed when Kuang asked him to repay the money he owed, the county magistrate provided another pathetic image. He described Kuang as "cold, hungry and impoverished", "without any place to stay", and "bereft of kin". In my extensive reading of homicide reports I have rarely seen this type of language. It was purposefully used to evoke pity for Kuang.

No amount of pity would save Kuang from his gruesome punishment, lingering death, but officials who reviewed the case could not help but notice the affective language used to describe Kuang's downward slide into penury. Kuang's life was a depressing illustration of rural distress and the disintegration of a family. He had lost 
his mother and brother to disease, sold his wife, and his only kin had harassed him and rejected him in his hour of need. He was homeless, penniless, jobless and alone, but he had tried to carry on as an itinerant peddler. While Kuang Wenqi had become a bare stick in the simplest definition of the term, officials who reviewed the case would never confuse him with the career criminals who used force and intimidation to survive. Kuang Wenqi was clearly flawed but his crime, no matter how heinous, was depicted as the final act of a pathetic man who had lost everything.

\section{CONCLUSION}

Historically, legal, moral, and political concerns combined to make capital cases an abiding and direct concern of Chinese emperors for whom compassion and mercy were considered hallmarks of virtuous rule. The highly elaborate system of capital case and sentencing reviews were the institutional representation of these concerns. Ostensibly, the role of the county magistrate in adjudicating capital crimes was strictly limited. But, as the primary author or 'editor' of the trial record, the county magistrate was uniquely positioned to influence superior judicial officials through his presentation of the facts, construction of the narrative, and selective quotation of depositions. ${ }^{59}$ Ironically, although the autumn assizes centralized review of capital cases to an unprecedented degree, the higher the level of judicial administration and the more removed from the original jurisdiction, the more dependent officials were on the information that the county magistrate provided in his case record. I would argue that the same editorial techniques that were used to expedite judicial review and to encourage leniency could also be used to present a more complex picture understanding of the connection between economic distress and violent crime.

When it came to understanding the true nature of crime, no one in the judicial bureaucracy was better informed than the county magistrate. The emotionally charged crime of rape provides another telling example of the gap between official perception and social reality. As Janet Theiss has found "contrary to the assumptions of much judicial discussion on rape, most cases of sexual assault and adultery involved not male outsiders but neighbors, friends, and quite often even relatives." ${ }^{60}$ Theiss' conclusion is consistent with Lai Huimin and Xu Siling's study of rape in eighteenth-century $\mathrm{China}^{61}$ as well as contemporary research of sexual assaults. ${ }^{62}$ The apparent discrepancy between the real-world threat of bare stick rapists emphasized in imperial rhetoric and the social reality of the crime illustrates

$59 \quad$ Karasawa (1995, pp. 212-250). It should be noted that Karasawa's cases are from the last decade of the Qing when, what I have called, the routinization of capital case reporting had been firmly established. In fact the increased 'streamlining' of capital case reporting was already evident over the course of the Qianlong reign.

60 Theiss (2004, p. 10).

${ }^{61}$ See Lai, Xu (1998). Lai and Xu also found that most cases of sexual assault or harassment involved a male who was known to the victim. Sexual assault and harassment are difficult crimes to study under the best of circumstances. Neither Theiss nor Lai and Xu, attempts a systemic sampling of the tens of thousands extant case records available, but their findings are similar to contemporary studies.

62 Available at [http://www.nij.gov/topics/crime/rape-sexual-violence/victims-perpetrators.htm] (accessed 29 May 2013). Modern studies indicate that victims and perpetrators are often known to each other. 
the dilemma of grass-roots judicial officials. While the emphasis on the bare stick as sexual predator was largely a product of ill-informed 'criminal profiling' at the highest levels of judicial administration, judicial discourse made the bare stick the scapegoat and legislation targeted him for severe punishment. But as Theiss notes, regardless of whom they arrested and prosecuted, "magistrates were confronted with a society that looked quite different from that imagined in morality handbooks". ${ }^{63}$ Thus, in the discharge of their judicial duties, local magistrates had to employ subtly in their reports. As Kuhn clearly demonstrated in his reconstruction of the sorcery scare of 1768, judicial officials who challenged imperial perceptions of crime did so at their own peril.

A close study of the case report suggests that, in addition to fulfilling the strict requirements of their judicial duties, some county magistrates used these account to instill awareness in superior officials of the harsh conditions faced by the rural poor. The message conveyed from Shandong was stark. The luckless tenant equated the loss of his livelihood with the death of his family. The hapless gambler belied the argument that hired laborers' could count on their employers to substitute for the security of the family. Finally, Kuang Wenqi's life story was a painful panorama of the destruction of one man's family. As we have seen in the case of sexual crimes, recent studies indicate a significant gap between social reality and imperial perceptions. Just as any competent county magistrates would have been aware that the crime of rape was far more complicated than the imperial rhetoric indicated, the cases recounted above demonstrate that county magistrates in Shandong were firsthand witnesses to the destruction of the family, a phenomenon directly related to the emergence of bare sticks.

Clearly county magistrates were capable of recognizing the complexity of the plight of the downwardly mobile peasant, even those who committed multiple homicides of children. It is hard to imagine a case in which the legal, moral, and political tenor of the time was more heavily stacked against the criminals. Local officials were undoubtedly well aware of the official attitude and they could have easily echoed the strident tones of imperial condemnations of rogue males. Nevertheless, at least in their representations of these crimes to their superiors, the county magistrates attempted to impart some knowledge of the sense of betrayal and the abject poverty that drove men to kill. Leniency for those who willfully killed was out of the question, yet even the perpetrators of these horrible crimes were not denied their humanity. To varying degrees the three cases employed evocative descriptions of rural distress and nuanced depictions of peasant families and hired laborers living on the margins of subsistence to issue a stark warning to central government authorities. Poverty was killing the family in Shandong.

Thomas Buoye Associate Professor of History University of Tulsa Department of History 800 S. Tucker Drive Tulsa, OK 74104 thomas-buoye@utulsa.edu

$\overline{63}$ Theiss (2004, p. 154). 


\section{REFERENCES}

Alabaster, E., Dips into an Imperial Law Officer's Compendium, Monumenta Serica, 1936, 2, pp. 426-436.

Bourgon, J., The Principle of Legality and Legal Rules in the Chinese Legal Traditio', in Delmas-Marty, M., Will, P.-E., Norberg, N. (Eds), China, Democracy, and Law: A Historical and Contemporary Approach, Leiden, Brill, 2012, pp. 169-188.

Buoye, T., Suddenly Murderous Intent Arose: Bureaucratization and Benevolence in Eighteenth-Century Qing Homicide Reports, Late Imperial China, December 1995, 16, 2, pp. 95-130.

Buoye, T., Manslaughter, Markets, and Moral Economy: Violent Disputes over Property Rights in Eighteenth-century China, Cambridge, Cambridge University Press, 2000.

Buoye, T., Filial Felons: Leniency and Legal Reasoning in Qing China, in Hegel, R.C., Carlitz, E. (Eds), Writing and Law in Late Imperial China: Crime, Conflict, and Judgment, Seattle, University of Washington Press, 2007, pp. 109-124.

Chen B., Zhongguo liumang shi [History of Chinese Rogues], Beijing, Chinese Academy of Social Sciences Press, 1993.

Dai Y., The Sichuan Frontier and Tibet: Imperial Strategy in the Early Qing, Seattle, University of Washington Press, 2009.

Edwards, R. R., The Role of Case Precedent in the Qing Judicial Process as Reflected in Appellate Rulings, in Cohen, J.A., Hsu, C.S. (Eds), Understanding China's Legal System: Essays in Honor of Jerome A. Cohen, New York, New York University, 2003, pp. 180209.

Elman, B., A Cultural History of Civil Examinations in Late Imperial China, Berkeley, University of California Press, 2000.

Feng Y., A History of Chinese Philosophy (vol.1), Princeton, Princeton University Press, 1983.

Ho, P., Studies on the Population of China, 1368-1953, Cambridge, MA., Harvard University Press, 1959.

Huang L., A Complete Book Concerning Happiness and Benevolence: A Manual for Local Magistrates in Seventeenth-Century China (translated and edited by Chu Djang), Tucson, Arizona, University of Arizona Press, 1984.

Karasawa, Y., Between Speech and Writing: Textuality of the Written Record of Oral Testimony in Qing Legal Cases, Chugoku shakai to bunka, 1995, 10, pp. 212-250.

Kuhn, P. A., Soulstealers: The Chinese Sorcery Scare of 1768, Cambridge MA., Harvard University Press, 1990.

Lai H., Xu S., Qingyu yu xingfa: Qing qianqi fanjian anjian di lishi jiedu (1644-1795) [Lust and Criminal Law: Historical Study of Rape Cases in the Early Qing, 1644-1795], Jindai Zhongguofunushi yanjiu, 1998, 7, pp. 31-74.

Li S., Qingdai beifang nongdi liyong de tedian [Special characteristics of agricultural land use in northern China during the Qing dynasty], Zhongguo shehui jingji shi yanjiu (Chinese Social and Economic History Research), 1988, 3, pp. 31-34.

Lin M., From Sweet Potato to Silver: The New World and 18th-century China as Reflected in Wang Hui-tsu's Passage about Grain Prices, in Pohl, H. (ed.), The European Discovery of the World and Its Economic Effect on Pre-industrial Society, 1500-1800: Papers of the Tenth International Economic History Congress, Stuttgart, Franz Steiner, 1990.

Liu, K.C., Hong Liangji: On Imperial Malfeasance and China's Population Problem, in Wm. Bary, T. de, Lufrano, R. (Eds), Sources of Chinese Tradition, (vol. 2), New York, Columbia University Press, 1999, pp. 172-178.

MacCormack, G., The Lü Hsing : Problems of Legal Interpretation, Monumenta Serica, 19861987, 37, pp. 35-47. 
Mair, V., Language and Ideology in the Written Popularizations of the Sacred Edict, in Johnson, D., Nathan, A.J., Rawski, E.S. (Eds), Popular Culture in Late Imperial China, Berkeley, University of California Press, 1985, pp. 325-359.

Mann, S., Kuhn, P.A., Dynastic Decline and the Roots of Rebellion, in Fairbank, J.K. (ed.), The Cambridge History, Late Ch'ing, 1800-1911, (vol. 10, part I), Cambridge, CUP,1976, pp. 107-163.

Meijer, M.J., Murder and Adultery in Late Imperial China: A Study of Law and Morality, Leiden, Brill, 1991.

Myers, R.H., Wang, Y., Economic Developments, 1644-1800, in Peterson, W.J. (ed.), The Cambridge History of China, (vol. 9, part 1), New York, CUP, 2002, pp. 570-572.

Robinson, D., Bandits, Eunuchs, and the Son of Heaven: Rebellion and the Economy of Violence in mid-Ming China, Honolulu, University of Hawaii Press, 2001.

Rowe, W.T., Social Stability and Social Change, in Peterson, W.J. (ed.), The Cambridge History of China, Early Ch'ing, (vol. 9, part 1), Cambridge, CUP, 2002, pp. 473-562.

Sheng X., The Plum in the Golden Vase or Chin P'ing Mei (tranl. David Tod Roy), Princeton, Princeton University Press, 1993.

Sommer, M., Sex, Law, and Society in Late Imperial China, Stanford, Stanford University Press, 2000.

Spence, J., The Search for Modern China, New York, Norton, 1999.

Theiss, J., Disgraceful Matters: The Politics of Chastity in Eighteenth-Century China, Berkeley, University of California Press, 2004.

Wang W., Prosperity and Its Discontents : Contextualizing Social Protest in the Late Qianlong Reign, Frontiers of History in China, 2011, 6, 3, pp. 347-369.

Yang G., Ming Qing tudi wenshu yanjiu [Research on Ming Qing Land Documents], Beijing, Renmin Chubanshe, 1988.

Xue Y., Duli cunyi [Lingering Doubts upon Reading the Substatutes],Taipei, Chengwen Publisher, 1970.

Zhang G., Rogue Crime in the Criminal Law of the Ming and Qing Dynasties, Asian Studies Review, 2008, 5, 30, pp. 147-160.

Zhen Q., Pursuing perfection: formation of the Qing code (transl. Guanyuan Zhou), Modern China, 1995, 21, 3, pp. 310-344. 